\title{
WYDATKI NA UTRZYMANIE LOKALI MIESZKALNYCH A ZALEGŁOŚCI W OPŁATACH ZA MIESZKANIE W BUDŻETACH GOSPODARSTW DOMOWYCH
}

\begin{abstract}
W teorii ekonomii konsumpcja pojmowana jest jako proces zaspokojenia potrzeb ludzkich. Istnieje wiele podziałów i klasyfikacji potrzeb definiowanych jako ,pewien stan psychofizyczny człowieka, przejawiający się w subiektywnym poczuciu braku lub pożądania jakiegoś dobra lub stanu", powstałych na gruncie badań zarówno z zakresu psychologii jak i ekonomii. Niewątpliwe jedną z potrzeb podstawowych jest posiadanie mieszkania. Zakup mieszkania nie należy do wydatków konsumpcyjnych, ale już koszty użytkowania i utrzymania lokalu są stałą pozycją w budżetach gospodarstw domowych. Celem artykułu była identyfikacja trendów pojawiających się w strukturze wydatków konsumpcyjnych gospodarstw domowych, w szczególności związanych z utrzymaniem mieszkań w latach 2000-2015. Poziom wydatków na utrzymanie mieszkania został porównany $\mathrm{z}$ rozmiarem zaległości $\mathrm{w}$ opłatach za mieszkania przy uwzględnieniu form własności lokali oraz wskaźnikami ubóstwa w Polsce i w UE. Zidentyfikowano, w których formach własności lokali występują najwyższe zaległości w opłatach za mieszkanie.
\end{abstract}

Słowa kluczowe: potrzeby mieszkaniowe, wydatki na utrzymanie mieszkania, zaległości w opłatach za mieszkanie.

\section{WSTECP}

Konsumpcja jest najbardziej powszechną czynnością człowieka, trwającą od momentu jego narodzin do kresu życia. Codzienność konsumowania różnego rodzaju dóbr sprawia, że jej sens odczuwamy niemal intuicyjnie. Są to wydatki gospodarstw domowych na zakup

${ }^{1}$ Dr inż. Agnieszka Napiórkowska-Baryła, Uniwersytet Warmińsko-Mazurski w Olsztynie, Katedra Ekonomiki Przestrzennej i Środowiskowej, ul. Oczapowskiego 4, 10-900 Olsztyn, autor korespondencyjny; e-mail: agnieszka.baryla@uwm.edu.pl.

Agnieszka Napiórkowska-Baryła, PhD Eng., University of Warmia and Mazury in Olsztyn, Department of Spatial and Environmental Economics, ul. Oczapowskiego 4, 10-900 Olsztyn, corresponding author; e-mail: agnieszka.baryla@uwm.edu.pl.

${ }^{2}$ Dr inż. Mirosława Witkowska-Dąbrowska, Uniwersytet Warmińsko-Mazurski w Olsztynie, Katedra Ekonomiki Przestrzennej i Środowiskowej, ul. Oczapowskiego 4, 10-900 Olsztyn; e-mail: m.witkowska@uwm.edu.pl.

Mirosława Witkowska-Dąbrowska, PhD Eng., University of Warmia and Mazury in Olsztyn, Department of Spatial and Environmental Economics, ul. Oczapowskiego 4, 10-900 Olsztyn; e-mail: m.witkowska@uwm.edu.pl. 
dóbr i usług. W teorii ekonomii konsumpcja pojmowana jest jako proces zaspokojenia potrzeb ludzkich. Potrzeba, jak podają K. Olechowski i P. Załęcki jest to ,pewien stan psychofizyczny człowieka, przejawiający się w subiektywnym poczuciu braku lub pożądania jakiegoś dobra lub stanu"3. Potrzeby ludzkie są bardzo zróżnicowane, a przy tym ciągle się zmieniają. Istnieje wiele podziałów i klasyfikacji potrzeb powstałych na gruncie badań zarówno z zakresu psychologii, jak i ekonomii, niemniej najbardziej popularną jest hierarchiczna teoria potrzeb A. Maslowa. Zgodnie $\mathrm{z}$ tą teorią zaspokojenie potrzeb niższego rzędu (potrzeby fizjologiczne, potrzeby bezpieczeństwa, przynależności) jest warunkiem zaspokojenia potrzeb wyższych (potrzeby uznania, samorealizacji). Z upływem lat pojawiają się głosy krytyczne, wskazujące na zbyt duże uogólnienie, ponieważ nie każdy człowiek ma uszeregowane potrzeby w ten sam sposób, co oznacza, że każdy ma inną hierarchię potrzeb, która zmienia się stosownie do posiadanej wiedzy, zasobności finansowej, rozwoju emocjonalnego itp. ${ }^{4}$. Zdaniem autorek dotyczy to jednak potrzeb wyższych, te niższe muszą być zaspokojone niezależnie od warunków wewnętrznych i zewnętrznych. Niewątpliwe jedną $\mathrm{z}$ potrzeb podstawowych jest posiadanie mieszkania. K. Krzeczkowski stwierdził, że „mieszkanie - w hierarchii potrzeb człowieka - zajmuje czołowe miejsce jako jedna z najistotniejszych pozycji spożycia indywidualnego, jest przecież równocześnie potrzebą społeczną, której sposób zaspokojenia wpływa jak mało co innego na każde środowisko ludz-

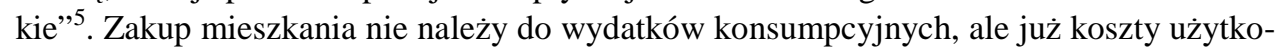
wania i utrzymania lokalu są stałą pozycją w budżetach gospodarstw domowych.

Celem artykułu była identyfikacja trendów pojawiających się w strukturze wydatków konsumpcyjnych gospodarstw domowych, w szczególności związanych z utrzymaniem mieszkań w latach 2000-2015. Poziom wydatków związanych z utrzymaniem mieszkania został porównany $\mathrm{z}$ rozmiarem zaległości w opłatach za mieszkanie przy uwzględnieniu form własności lokali oraz z wskaźnikami ubóstwa. Do przeprowadzenia analizy wykorzystane zostały dane GUS opublikowane w raporcie „Sytuacja społeczno-ekonomiczna gospodarstw domowych w latach 2000-2015" oraz w Banku danych lokalnych.

\section{GOSPODARSTWO DOMOWE JAKO PODMIOT SFERY KONSUMPCJI}

Jak zaznaczono we wstępie potrzeby ludzkie są różnorodne i każdy konsument hierarchizuje swój system potrzeb, jednakże mechanizm ich realizacji jest podobny i przebiega wg schematu na rys. 1.

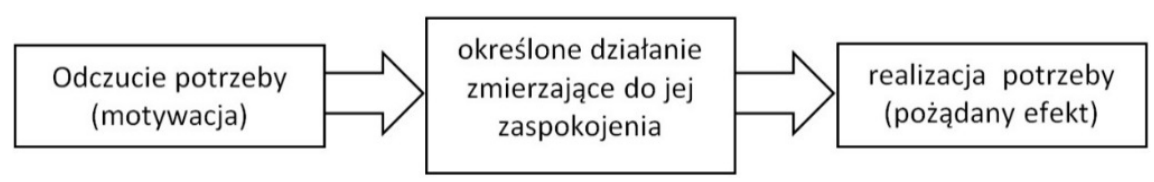

Rys. 1. Uproszczony model realizacji potrzeb

Źródło: A. Szelągowska, Finansowanie społecznego budownictwa mieszkaniowego..., s. 31.

\footnotetext{
${ }^{3}$ K. Olechowski, P. Załęcki, Stownik socjologiczny, Toruń 1999, s. 160.

4 A. Szelągowska, Finansowanie spotecznego budownictwa mieszkaniowego, Warszawa 2011, s. 33.

${ }^{5}$ K. Krzeczkowski, Kwestia mieszkaniowa w miastach polskich, Warszawa 1939, s. 16.
} 
Mimo różnorodności potrzeb E. Wiszniewski charakteryzuje je następującymi właściwościami ${ }^{6}$ :

- historyczność,

- nieograniczoność (czas, liczba, przestrzeń),

- ograniczoność zakresu i pojemności niektórych potrzeb (dotyczy zaspokojenia),

- różnice w intensywności ujawniania się poszczególnych grup potrzeb,

- komplementarność,

- mała substytucyjność,

- zaspokajanie potrzeb „wyższych” po zaspokojeniu potrzeb biologicznych.

Realizacji potrzeb służy konsumpcja. Kategoria konsumpcji jest złożona, wielowymiarowa i pojemna $w$ treści. Zawiera takie pojęcia, jak wspomniane już potrzeby, sposoby ich zaspokajania, wykorzystywanie różnorodnych dóbr materialnych i niematerialnych, warunki bytu, styl, poziom i jakość życia, odtwarzanie przedmiotów konsumpcji ${ }^{7}$. Cz. Bywalec i L. Rudnicki podają, że konsumpcja oznacza bezpośredni akt zaspokajania pewnej potrzeby przez zużycie - całkowite lub częściowe - określonego dobra lub usługi, powtarzalność tego aktu układa się w proces $^{8}$. W tym ujęciu konsumpcja dotyczy nie tylko zachowań konsumenta jako jednostki, ale także może być rozpatrywana jako proces obejmujący całe zbiorowości zaspokajające swoje potrzeby. W naukach ekonomicznych konsumpcję rozpatruje się jako zjawisko w skali makro- i mikroekonomicznej. J. Kramer podaje, że w ujęciu makroekonomicznym konsumpcja jest wielosystemowym zjawiskiem ekonomiczno-społecznym ${ }^{9}$. Obejmuje ona całą sferę spożycia $w$ jego podmiotowym, przedmiotowym i przestrzennym ujęciu w powiązaniu z czynnikami oddziaływującymi na proces konsumpcji. W ujęciu mikroekonomicznym konsumpcja odnosi się bezpośrednio do jednostki lub gospodarstwa domowego.

Głównymi podmiotami konsumpcji są gospodarstwa domowe. Definiowanie gospodarstwa domowego i pojmowanie jego istoty zmieniało się w czasie. Początkowe definicje traktowały gospodarstwo domowe jako zbiór rzeczy służących konsumpcji jednostki lub grupy osób wspólnie zamieszkujących i utrzymujących się. Następne w czasie definicje zaczęły uwzględniać również ujęcie podmiotowe, tj. osobę lub zespół osób wraz z charakteryzującymi je cechami demograficznymi, osobowościowymi, społecznymi ${ }^{10}$. A. Hodoly podaje, że „gospodarstwo domowe jest bazą ekonomiczną jednostki lub grupy osób powiązanych ze sobą więziami rodzinnymi lub więziami innego rodzaju, członkowie gospodarstwa zamieszkują razem (nawet jeśli są okresowo nieobecni, lecz pozostają całkowicie lub częściowo na utrzymaniu gospodarstwa), łączą swoje przychody (pieniężne i naturalne), zasoby dóbr materialnych oraz reprezentowaną przez siebie siłę roboczą w celu zaspokojenia potrzeb gospodarstwa jako całości i poszczególnych jej członków, przy czym mowa o potrzebach szeroko pojętego spożycia" ${ }^{11}$. We współczesnym definicyjnym ujęciu gospodarstwo domowe jest mikrojednostką, która produkuje dobra, gromadzi środki pieniężne

${ }^{6}$ E. Wiszniewski E., Ekonomika konsumpcji, Warszawa 1983, s. 108.

${ }^{7}$ K. Żelazna, I. Kowalczuk, B. Mikuta, Ekonomika konsumpcji. Elementy teorii, Warszawa 2002, s. 19.

8 Cz. Bywalec, L. Rudnicki, Podstawy ekonomiki konsumpcji, Kraków 1999, s. 8.

9 J. Kramer, Konsumpcja w gospodarce rynkowej, Warszawa 1997, s. 15.

${ }^{10}$ K. Żelazna, I. Kowalczuk, B. Mikuta, Ekonomika konsumpcji..., s. 31.

11 A. Hodoly, Gospodarstwo domowe i jego rola spoteczno-ekonomiczna, Warszawa 1971, s. 20. 
i rzeczowe i dysponuje nimi oraz organizuje proces konsumpcji. Celem działalności gospodarstwa domowego jest zaspokajanie potrzeb domowników poprzez dążenie do zagwarantowania im jak najlepszych warunków bytu, a więc poziomu i jakości życia. Cel ten jest jedną ze swoistych cech gospodarstwa domowego wyróżniającą je spośród innych jednostek gospodarujących.

Zakres i strukturę potrzeb zaspokajanych w gospodarstwie domowym kształtują ${ }^{12}$ :

- czynniki zewnętrzne, niezależne bezpośrednio od gospodarstw domowych, a związane z ogólnym stopniem i kierunkiem rozwoju społeczno-gospodarczego kraju (np. zasób dóbr konsumpcyjnych w gospodarstwie domowym, dostępność dóbr publicznych, podaż dóbr konsumpcyjnych oraz organizacja ich nabywania, poziom i relacje cen artykułów konsumpcyjnych),

- czynniki wewnętrzne, wynikające ze struktury społeczno-demograficzno-ekonomicznej gospodarstw domowych i ich członków (np. dochody gospodarstw domowych, liczba członków gospodarstw domowych - ich wiek i płeć, wykształcenie, aktywność zawodowa, zasoby wolnego czasu, zwyczaje i tradycje, systemy wartości, oddziaływanie wzorców konsumpcji, edukacja konsumenta (rys. 2).

\begin{tabular}{|c|c|c|}
\hline \multicolumn{3}{|c|}{ MAKROOTOCZENIE } \\
\hline \multicolumn{3}{|c|}{ MIKROOTOCZENIE } \\
\hline \multicolumn{3}{|c|}{ GOSPODARSTWO DOMOWE } \\
\hline Układ podmiotowy & Układ przedmiotowy & Układ funkcjonalny \\
\hline $\begin{array}{l}\text { konsumenci - członkowie } \\
\text { gospodarstw domowych i ich } \\
\text { cechy społeczno- } \\
\text { demograficzno- ekonomiczne }\end{array}$ & $\begin{array}{l}\text { środki pieniężne, } \\
\text { domowa infrastruktura } \\
\text { konsumpcyjna }\end{array}$ & $\begin{array}{l}\text { funkcje gospodarstwa } \\
\text { domowego, proces } \\
\text { zaspokojenia potrzeb }\end{array}$ \\
\hline \multicolumn{3}{|c|}{$\begin{array}{l}\text { - infrastruktura komunalno-bytowa i rynkowa } \\
\text { - } \quad \text { przedsiębiorstwa i instytucje rynkowe }\end{array}$} \\
\hline \multicolumn{3}{|c|}{$\begin{array}{l}\text { - uwarunkowania społeczne, kulturowe, środowiskowe, gospodarcze } \\
\text { - instytucje centralne i regionalne }\end{array}$} \\
\hline
\end{tabular}

Rys. 2. Struktura gospodarstwa domowego i jego otoczenie

Źródło: Z. Kędzior, Relacje konsument-gospodarstwo domowe jako przedmiot badań marketingowych [w:] Kontrowersje wokót marketingu w Polsce - tożsamość, etyka przysztość, red. L. Garbarski, Warszawa 2004, https://books.google.pl/books?isbn=8389437333 (dostęp: 10.10 .2017 r.).

\section{WYDATKI NA UTRZYMANIE MIESZKANIA}

Przedmiotem konsumpcji gospodarstw domowych są dobra i usługi, klasyfikowane często według skali potrzeb na: podstawowe, wyższego rzędu i luksusowe. Ze względu na trwałość dobra dzielone są następująco ${ }^{13}$ :

- dobra trwałego użytku, takie, które nie zużywają się w jednorazowym akcie konsumpcji, ich czas użytkowania jest stosunkowo długi a decyzje podejmowane przy ich wyborze są z reguły decyzjami niezrutynizowanymi (mieszkanie z wyposażeniem, meble, samochody itp.);

\footnotetext{
${ }^{12}$ Cz. Bywalec, L. Rudnicki, Podstawy ekonomiki konsumpcji, Kraków 1999, s. 38-62.

${ }^{13}$ Encyklopedia Zarzadzania, https://mfiles.pl/pl/ (dostęp: 10.10.2017 r.).
} 
- dobra nietrwałe (np. żywność) i półtrwałego użytkowania (odzież, obuwie, książki, zabawki, środki czystości itp.);

- usługi, (usługi kosmetyczne, fryzjerskie, remontowe, czy opieka medyczna itp.).

Wśród dóbr trwałego użytkowania za podstawowe dobro uznawane jest mieszkanie, które charakteryzuje się specyficznymi cechami wyróżniającymi je spośród innych dóbr konsumpcyjnych. Zaliczyć można do nich trwałość, długowieczność, niemobilność związaną z konkretną lokalizacją przestrzenną i bardzo wysoki koszt jednostkowy nabycia ${ }^{14}$. Mieszkanie jest również jednym z istotnych determinantów wyróżniających gospodarstwa domowe jako jednostkę społeczno-gospodarczą. Zwraca uwagę to, że gospodarstwo domowe, jako podmiot konsumpcji, składa się z jednostki lub grupy osób, które są połączone ze sobą nie tylko więzami rodzinnymi, ale również wspólnym mieszkaniem i wspólnym gospodarowaniem. Poziom miesięcznych wydatków na utrzymanie mieszkania w zróżnicowaniu na miasto i wieś podano w tabeli 1 .

Tabela 1. Przeciętne miesięczne wydatki na osobę w gospodarstwie domowym w wybranych latach w miastach i na wsi (w zł)

\begin{tabular}{|c|c|c|c|c|}
\hline \multirow{2}{*}{ Wyszczególnienie } & \multicolumn{4}{|c|}{ Lata } \\
\hline & 2000 & 2005 & 2010 & 2015 \\
\hline Wydatki ogółem (zł na osobę) & 584 & 690 & 998 & 1091 \\
\hline $\begin{array}{l}\text { w tym: } \\
\text { 1) użytkowanie mieszkania lub domu i nośniki energii; } \\
\text { 2) wyposażenie mieszkania i prowadzenie gospodarstwa } \\
\text { domowego }\end{array}$ & $\begin{array}{c}106 \\
31\end{array}$ & $\begin{array}{l}136 \\
34\end{array}$ & $\begin{array}{l}202 \\
52\end{array}$ & $\begin{array}{c}219 \\
54\end{array}$ \\
\hline Wydatki ogółem - miasta & 662 & 778 & 1125 & 1225 \\
\hline $\begin{array}{l}\text { w tym: } \\
\text { 1) użytkowanie mieszkania lub domu i nośniki energii; } \\
\text { 2) wyposażenie mieszkania i prowadzenie gospodarstwa } \\
\text { domowego }\end{array}$ & $\begin{array}{l}129 \\
35 \\
\end{array}$ & $\begin{array}{l}159 \\
38 \\
\end{array}$ & $\begin{array}{l}229 \\
59 \\
\end{array}$ & $\begin{array}{l}252 \\
61 \\
\end{array}$ \\
\hline Wydatki ogółem - wieś & 466 & 550 & 800 & 883 \\
\hline $\begin{array}{l}\text { w tym: } \\
\text { 1) użytkowanie mieszkania lub domu i nośniki energii; } \\
\text { 2) wyposażenie mieszkania i prowadzenie gospodarstwa } \\
\text { domowego }\end{array}$ & $\begin{array}{r}73 \\
25\end{array}$ & $\begin{array}{l}99 \\
28\end{array}$ & $\begin{array}{l}158 \\
41\end{array}$ & $\begin{array}{r}169 \\
44\end{array}$ \\
\hline
\end{tabular}

Źródło: opracowanie własne na podstawie stat.gov.pl/obszary-tematyczne/warunki-zycia/dochodywydatki-i-warunki-zycia-ludnosci/sytuacja-spoleczno-ekonomiczna-gospodarstw-domowych-w-latach-2000-2015-zroznicowanie-miasto-wies,5,2.html (dostęp: 10.10.2017 r.).

W latach 2000-2015 w ślad za dochodami prawie dwukrotnie wzrosły również nominalnie wydatki gospodarstw domowych. Kwota przeciętnych miesięcznych wydatków w gospodarstwach domowych na osobę wzrosła z 584 zł w 2000 r. do 1091 zł w 2015 r. Większe wydatki ponosiły gospodarstw domowe w miastach niż na wsi. W latach 2000 -2015 nieznacznie zmniejszyła się różnica pomiędzy wydatkami w miastach i na wsi. W 2000 r. przeciętne miesięczne wydatki na wsi stanowiły $79,8 \%$ przeciętnych miesięcznych wydatków ogółem i 70,4\% wydatków w miastach. Natomiast w 2015 r. średnie

${ }^{14}$ A. Andrzejewski, Polityka mieszkaniowa, Warszawa 1987, s. 28-31. 
wydatki na wsi osiągnęły 80,9\% średniej krajowej (wzrost o 1,1 p.p.) i 72,1\% wartości w miastach (wzrost o 1,7 p.p.) (GUS 2016). 95-97\% wydatków ogółem stanowiły wydatki na towary i usługi konsumpcyjne bez względu na miejsce zamieszkania gospodarstw domowych. Największy udział w strukturze wydatków konsumpcyjnych w 2015 r. miały wydatki na żywność i napoje bezalkoholowe, których poziom wynosił w przeliczeniu na jedną osobę miesięcznie - 262,32 zł i 24,0\% w wydatkach ogółem. Jednakże w odniesieniu do 2000 r. nastąpiło istotne obniżenie tego odsetka - o 7,6 p.p., szczególnie w wiejskich gospodarstwach domowych. Zjawisko to jest zgodne z prawem Engla, mówiącym, że w miarę wzrostu dochodów gospodarstw domowych, obserwuje się spadek procentowego udziału wydatków na żywność i inne dobra podstawowe. Wydatki na mieszkanie (użytkowanie mieszkania i nośniki energii) stanowiły drugą co do wielkości pozycję wydatków konsumpcyjnych w gospodarstwach domowych. Wydatki na mieszkanie w ujęciu per capita stanowią w przewadze koszty stałe, niezależne od liczby osób (np. ogrzewanie). Wpływ na nie ma również charakter własności zasobów mieszkaniowych i ich wyposażenie w instalacje. Nie bez znaczenia są tu możliwości finansowe i preferencje mieszkaniowe użytkowników lokali, a także gospodarność ich dysponentów. W 2000 r. - w przeliczeniu na osobę miesięcznie wynosiły 106 zł w 2015 r. - 219 zł, co w ujęciu względnym dawało 18,2\% i 20,1\% przeciętnych wydatków gospodarstw domowych. Udział tej grupy wydatków w latach 2000-2015 miał tendencję lekko wzrostową, szczególnie na wsi, gdzie nastąpił wzrost o 3,4 p.p. ${ }^{15}$.W okresie transformacji ustrojowej i ,ekonomizacji” gospodarki mieszkaniowej wydatki na utrzymanie mieszkania wzrosły znacząco - o ile w latach 70. i 80. ich udział stanowił kilka procent w wydatkach polskich gospodarstw domowych $(8,4 \% \mathrm{w} 1971 \mathrm{r}$., 7,2\% w 1975 r., 6,1\% w 1980 r., 5,6\% w 1985 r. i 4,8\% w 1989 r.), to w ostatnich piętnastu latach utrzymują się na zbliżonym poziomie ok. $20 \%{ }^{16}$. Cały czas obserwuje się różnice zarówno w dochodach rozporządzalnych jak i w wydatkach pomiędzy gospodarstwami domowymi w mieście i na wsi. Nie inaczej jest również w wydatkach na utrzymanie mieszkania, które w miastach stanowiły w 2000 r. 121\%, a w 2015 r. 114,7\% średniej krajowej. Wydatki w gospodarstwach domowych na wsi wynosiły odpowiednio 68,3\% i 77\%. Zmniejsza się stopniowo rozpiętość wydatków na utrzymanie mieszkania pomiędzy miastem a wsią z 53 p.p. w 2000 r. do 38 p.p. w 2015 r. Odwrotną tendencję obserwuje się w drugiej grupie wydatków konsumpcyjnych związanych $\mathrm{z}$ utrzymaniem mieszkania a mianowicie wyposażeniem mieszkania i prowadzeniem gospodarstwa domowego. Ich udział w strukturze wydatków konsumpcyjnych w latach 2000-2015 systematycznie malał, na wsi o 0,3 p.p., w mieście o 0,4 p.p.

\section{ZALEGŁOŚCI W OPŁATACH ZA MIESZKANIE}

Z analizy wysokości wydatków na utrzymanie mieszkania wynika, że ta pozycja systematycznie rośnie stanowiąc ok. 20\% udział w wydatkach konsumpcyjnych gospodarstw domowych. Celowe więc wydaje się porównanie tego zjawiska z rozmiarem zaległości w opłatach za użytkowanie mieszkania (tabela 2). Do porównania, ze względu na niekom-

\footnotetext{
15 stat.gov.pl/obszary-tematyczne/warunki-zycia/dochody-wydatki-i-warunki-zycia-ludnosci/ sytuacja-spoleczno-ekonomiczna-gospodarstw-domowych-w-latach-2000-2015-zroznicowaniemiasto-wies, 5,2.html (dostęp: 10.10.2017 r.).

${ }^{16}$ M. Gorczyca, Zaległości w opłatach za użytkowanie mieszkań, 2017, http://www.administrator24.info/artykul/id9688,zaleglosci-w-oplatach-za-uzytkowanie-mieszkan (dostęp: 10.10.2017 r.).
} 
pletne dane z lat wcześniejszych, jako pierwszy przyjęto rok 2003. Liczba mieszkań zadłużonych w 2015 r. wynosiła 1569,4 tys., co przy zasobie mieszkaniowym wynoszącym 14120 tys. stanowi $11 \%$. W 2003 r. odsetek ten wynosił $16 \%-2056$ tys. mieszkań zadłużonych wśród 12596 tys. mieszkań ogółem. Ma to przełożenie na kwoty zaległości, które również maleją - 2221,33 mln zł w 2003 r., 1877 mln zł w 2009 r. i $1282 \mathrm{mln}$ zł w 2015 r. Gros zaległości wygenerowali użytkownicy zalegający z opłatami ponad trzy miesiące. Stanowiąc 30,2\% ogólnej liczby dłużników, ważyli oni w 68,9\% wartości zadłużeń. Średnia kwota zadłużenia w 2015 r. wynosiła blisko 1,2 tys. zł. Najwyżej zadłużeni są lokatorzy mieszkań zakładowych, gdzie średnie zadłużenie wynosi blisko 2,3 tys. zł, najniższe 950 zł charakteryzuje mieszkańców spółdzielni mieszkaniowych. Rozpatrując zaległości w opłatach za mieszkanie ze względu na strukturę własnościową najwyższa liczba mieszkań zadłużonych występuje w zasobie gminnym. Z 1314 tys. mieszkań, w 2003 r., 559,3 tys. (42,5\%) miało zaległości. W wyniku prywatyzacji zasób gminnych lokali w $2015 \mathrm{r}$. zmniejszył się do 886,7 tys., z czego 335,1 tys. (37,5\%) było zadłużonych. Podobną tendencję obserwuje się wśród lokali spółdzielczych, których generalnie w zasobie mieszkań również ubywa, z powodu możliwości ustanawiania odrębnej własności lokalu. Maleje również odsetek mieszkań spółdzielczych z zaległościami w opłatach za mieszkanie. $\mathrm{Na}$ podobnym poziomie pozostaje odsetek zadłużonych mieszkań będących w posiadaniu towarzystw budownictwa społecznego (21,5\% w 2003 r. i 20\% w 2015 r.) i mieszkań osób fizycznych funkcjonujących w wspólnotach mieszkaniowych. Odsetek mieszkań z zaległościami wynosi ok. 15\%. Natomiast tendencję wzrostową w zaległościach obserwuje się w przypadku lokali należących do zakładów pracy (16,7\% w 2003 r. i 21,5\% w 2015 r.).

Przy utrzymującym się od wielu lat wzroście wydatków konsumpcyjnych na utrzymanie mieszkania pozytywnym zjawiskiem jest spadek liczby i odsetka mieszkań zadłużonych oraz sumarycznych kwot zaległości. Może to wynikać większej dyscypliny w gospodarowaniu budżetami gospodarstw domowych. Niewątpliwie jednak ma to związek z pozytywnymi tendencjami w sytuacji makroekonomicznej kraju. Rosnące płace i malejące bezrobocie wpływają na powolne, ale systematyczne ograniczanie strefy ubóstwa w Polsce. Znaczenie pojęcia „ubóstwo” jest powszechnie znane i rozpoznane na gruncie badań z zakresu polityki społecznej. Najprościej można określić, że jest to trwały brak środków materialnych niezbędnych do zabezpieczenia potrzeb życiowych, sytuujący zarówno poszczególne jednostki ludzkie, gospodarstwa domowe, jak i całe grupy społeczne na poziomie minimum egzystencji lub poniżej tego poziomu.

Bieda stanowi zagrożenie dla realizacji celów i zadań życiowych ${ }^{17}$. Zarówno w języku potocznym, jak w literaturze przedmiotu używa się zamiennie pojęć: bieda, ubóstwo, niedostatek, krytyczna sytuacja życiowa, upośledzenie społeczne, deprywacja społeczna, marginalizacja. Zróżnicowanie językowe wskazuje na niejednoznaczność pojęcia. Zjawisko ubóstwa jest złożone i wielowymiarowe, ma zarówno aspekty ilościowe (np. wskaźnik dochodu gospodarstwa domowego), jak i jakościowe (inne wskaźniki sytuacji materialnej np. posiadanie pewnych dóbr, dostęp do takich wartości, jak wykształcenie czy ochrona zdrowia). Często trudno znaleźć jednoznaczne kryterium, na podstawie którego można stwierdzić, czy dane gospodarstwo domowe jest ubogie ${ }^{18}$. Rozmiary ubóstwa (skrajnego,

\footnotetext{
17 www.kns.gower.pl/slownik/slownik.htm (dostęp: 10.10.2017 r.).

${ }^{18}$ R. Gierszewska, J. Łopato, Zamożność, dochody, ubóstwo, świadczenia społeczne [w:] Polityka społeczna, red. G. Firlit-Fesnak i M. Szylko-Skoczny, Warszawa 2009, s. 240.
} 


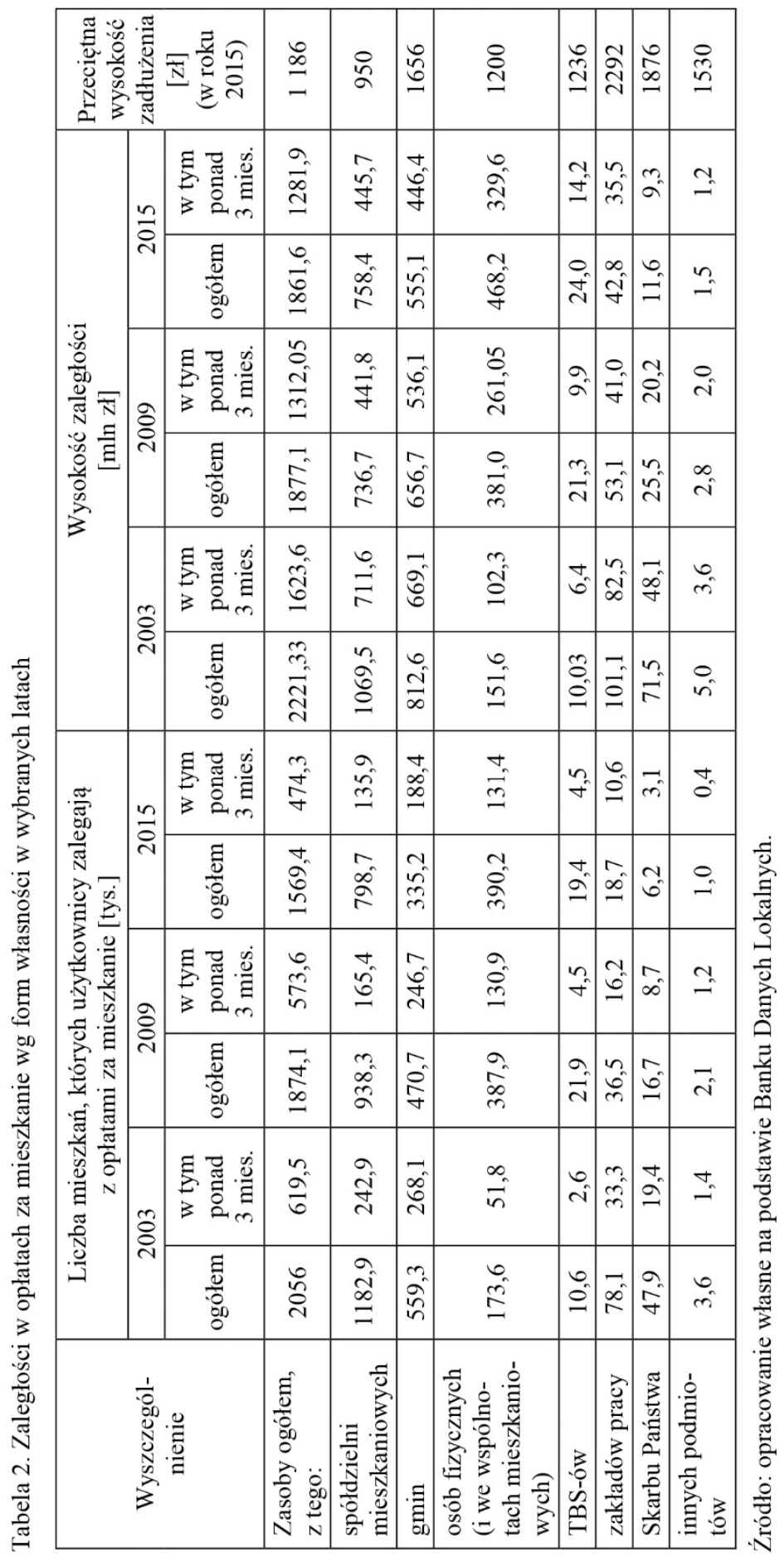


relatywnego, ustawowego) są cyklicznie szacowane przez GUS na podstawie wyników badania budżetów gospodarstw domowych (rys. 3).

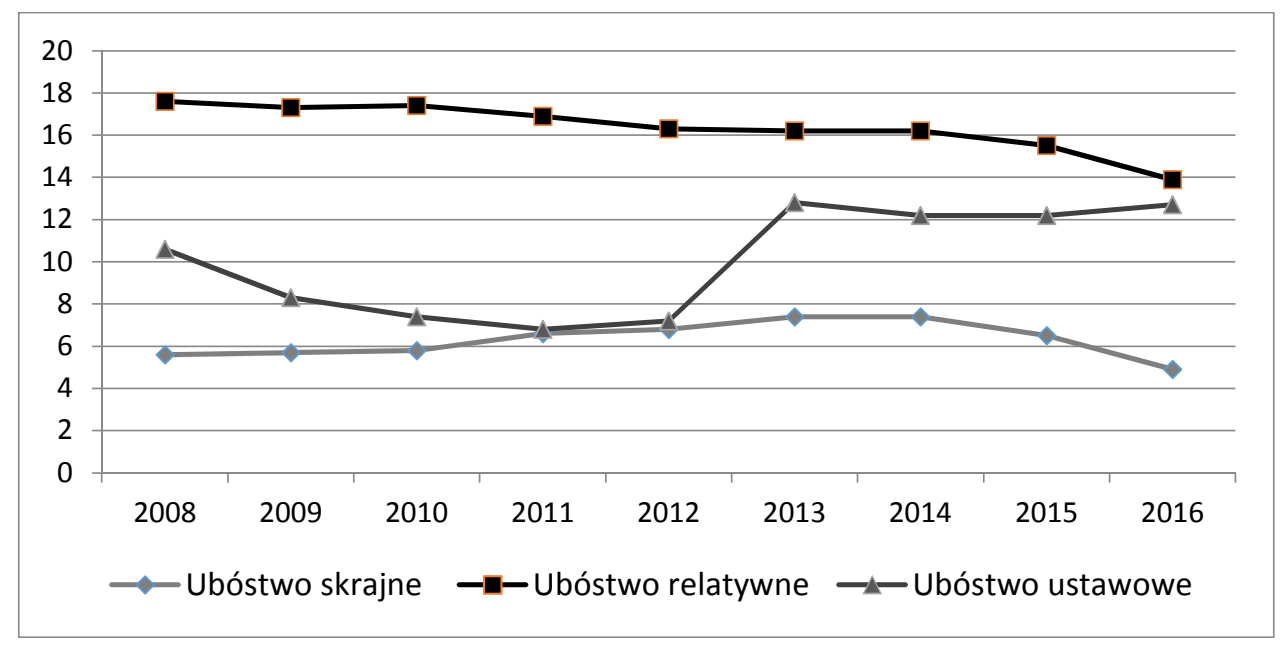

Rys. 3. Zasięg ubóstwa w Polsce w latach 2008-2016 wg przyjętych w danym roku granic ubóstwa $\%$ osób w gospodarstwach domowych

Źródło: opracowanie własne na podstawie www.stat.gov.pl/obszary-/warunki-zycia/ubostwo-pomocspoleczna/zasiegubóstwaekonomicznego-w-polsce-w-2016-r-14,3.html (dostęp: 10.10.2017 r.).

Problem ograniczania ubóstwa jest również jednym z priorytetów Unii Europejskiej. W Strategii Europa 2020 przyjęto, iż podstawowym wskaźnikiem służącym monitorowaniu postępów w realizacji działań w ramach celu 5 (ograniczenie liczby osób zagrożonych ubóstwem) będzie złożony wskaźnik zagrożenia ubóstwem lub wykluczeniem społecznym, uwzględniający trzy mierniki cząstkowe. W związku z tym, wskaźnik ten definiowany jest jako odsetek osób zagrożonych ubóstwem relatywnym lub pogłębioną deprywacją materialną, lub żyjących w gospodarstwach domowych o bardzo niskiej intensywności pracy (tabela 3).

Z badania EU-SILC ${ }^{19}$ wynika, iż w 2016 r. ubóstwem lub wykluczeniem społecznym w Polsce dotkniętych było ok. 22\% mieszkańców Polski. Rok 2016 był kolejnym, w którym odnotowano spadek wartości wskaźnika zagrożenia ubóstwem lub wykluczeniem społecznym. W porównaniu z 2015 r. wartość tego wskaźnika zmalała o 1,5 p.p. (z 23,4\% do 21,9\%). Podobnie jak w latach poprzednich, spadek wartości wskaźnika zagrożenia ubóstwem lub wykluczeniem społecznym w największej mierze wynikał z obniżenia w okresie wskaźnika pogłębionej deprywacji materialnej (z 8,1\% do 6,7\%). Wskaźnik pogłębionej deprywacji materialnej (Severely materially deprived people) definiowany jest jako odsetek

${ }^{19}$ Podstawą prowadzenia systematycznych analiz dotyczących zasięgu i społecznego zróżnicowania ubóstwa w Unii Europejskiej są wyniki prowadzonego przez wszystkie kraje członkowskie Europejskiego Badania Dochodów i Warunków Życia, zwanego w skrócie EU SILC (EU Statistics on Income and Living Condition). 
osób w gospodarstwach domowych deklarujących brak możliwości zaspokojenia ze względów finansowych co najmniej 4 z 9 wymienionych poniżej potrzeb:

1) opłacenia tygodniowego wyjazdu wszystkich członków gospodarstwa domowego na wypoczynek raz w roku,

2) spożywania mięsa, ryb (lub wegetariańskiego odpowiednika) co drugi dzień,

3) ogrzewania mieszkania odpowiednio do potrzeb,

4) pokrycia niespodziewanego wydatku (w wysokości odpowiadającej miesięcznej wartości granicy ubóstwa relatywnego, przyjętej w danym kraju, w roku poprzedzającym badanie),

5) terminowego regulowania opłat związanych z mieszkaniem, spłatą rat i kredytów,

6) posiadania telewizora kolorowego,

7) posiadania samochodu,

8) posiadania pralki,

9) posiadania telefonu (stacjonarnego lub komórkowego $)^{20}$.

Tabela 3. Wskaźnik zagrożenia ubóstwem lub wykluczeniem społecznym w Polsce i w Unii Europejskiej w latach 2008-2016

\begin{tabular}{|l|c|c|c|c|}
\hline \multirow{2}{*}{ Nazwa wskaźnika } & & \multicolumn{3}{|c|}{ Rok } \\
\cline { 3 - 5 } & & 2008 & 2015 & 2016 \\
\cline { 3 - 5 } & & $\%$ osób w gospodarstwach domowych \\
\hline \multirow{2}{*}{$\begin{array}{l}\text { Wskaźnik zagrożenia ubóstwem } \\
\text { relatywnym }\end{array}$} & Polska & 16,9 & 17,6 & 17,3 \\
\cline { 2 - 5 } $\begin{array}{l}\text { Wskaźnik pogłębionej } \\
\text { deprywacji materialnej }\end{array}$ & Unia Europejska & 16,5 & 17,3 & b.d. \\
\hline $\begin{array}{l}\text { Wskaźnik bardzo niskiej } \\
\text { intensywności pracy } \\
\text { w gospodarstwie domowym }\end{array}$ & Polska & 17,5 & 8,1 & 6,7 \\
\hline $\begin{array}{l}\text { Wskaźnik zagrożenia } \\
\text { ubóstwem lub wykluczeniem } \\
\text { społecznym }\end{array}$ & Polska & 8,5 & 8,1 & b.d. \\
\cline { 2 - 5 } & Unia Europejska & 9,2 & 10,7 & 6,4 \\
\cline { 2 - 5 } & Unia Europejska & $\mathbf{3 0 , 5}$ & $\mathbf{2 3 , 4}$ & $\mathbf{2 1 , 9}$ \\
\hline
\end{tabular}

Źródło: https://stat.gov.pl/obszary-tematyczne/warunki-zycia/ubostwo-pomoc-spoleczna/podstawowe-dane-dotyczace-zasiegu-ubostwa-w-polsce-w-2016-r-,19,1 (dostęp: 10.10.2017 r.).

W przypadku dwóch pozostałych wskaźników cząstkowych, tj. wskaźnika zagrożenia ubóstwem relatywnym oraz wskaźnika bardzo niskiej intensywności pracy w gospodarstwach domowych odnotowano jedynie nieznaczne spadki ich wartości (odpowiednio z $17,6 \%$ w 2015 r. do $17,3 \%$ w 2016 r. oraz z 6,9\% do 6,4\%).

Mimo braku wiarygodnych danych na ten temat, panuje powszechna opinia, że część zaległości w opłatach za użytkowanie mieszkania wynika z braku możliwości skutecznej ich windykacji (ograniczona możliwość eksmisji w stosunku do tej części zadłużonych, która celowo zalega z opłatami).

${ }^{20}$ stat.gov.pl/metainformacje/słownik-pojec/pojecia-stosowane-w-statystyce-publicznej (dostęp: 10.10.2017 r.). 


\section{PODSUMOWANIE}

Wydatki konsumpcyjne gospodarstw domowych od wielu lat mają stabilną strukturę, która wynika z hierarchii potrzeb ludzkich. Pierwszą pozycję zajmują wydatki na żywność i napoje bezalkoholowe. Drugą zajmują wydatki na utrzymanie mieszkania, które systematycznie rosły wraz ze wzrostem kosztów utrzymania zasobów lokalowych, osiągając ok. 20-procentowy udział w wydatkach gospodarstw domowych. Niezmiennie występują różnice zarówno w dochodach rozporządzalnych jak i w wydatkach na utrzymanie mieszkania pomiędzy gospodarstwami domowymi w mieście i na wsi, jednakże stopniowo zmniejsza się ich rozpiętość. Przy tak istotnym udziale w wydatkach konsumpcyjnych ogółem, naturalnym zjawiskiem są zaległości w opłatach za mieszkanie. Odsetek mieszkań zadłużonych jednak systematycznie maleje, w 2015 r. wynosił 11\%, dla porównania w 2003 r. - 16\%. Gros zaległości generują użytkownicy długoterminowo zalegający z opłatami (ponad 3 miesiące). Stanowiąc 30\% ogólnej liczby dłużników, tworzyli oni blisko $70 \%$ wartości zadłużeń. Pomijając kwestie wspomnianej wcześniej skuteczności windykacji długów i pomimo korzystnych wskaźników ekonomicznych przekładających się na zmniejszenie liczy gospodarstw domowych żyjących w ubóstwie, sytuacja wyraźnie wskazuje na niedostatki w zakresie pomocy mieszkaniowej. Kwestie związane z zabezpieczeniem potrzeb mieszkaniowych zgodnie z Konstytucją i ustawami stanowią zadanie własne gmin. Gminy mają do dyspozycji wiele instrumentów do realizacji tych zadań, ale w przypadku gospodarstw domowych z zaległościami mieszkaniowymi główną rolę pełnią dodatki mieszkaniowe i energetyczne. Idea dodatków mieszkaniowych zakłada pomoc publiczną w zakresie utrzymania mieszkań, niezależnie od ich statusu - lokatorskiego bądź własnościowego, jeżeli uprawniony nie jest w stanie samodzielnie pokryć wydatków na ich utrzymanie. Są to więc instrumenty socjalnej polityki mieszkaniowej, które powinny trafiać do najuboższych gospodarstw domowych. Blisko $42 \%$ kwoty wypłacanych dodatków mieszkaniowych trafia do gospodarstw domowych zajmujących mieszkania komunalne, z których jednocześnie $37,5 \%$ zalega z opłatami ${ }^{21}$. Brak możliwości zabezpieczenia podstawowych potrzeb mieszkaniowych pozwala stwierdzić, że są to gospodarstwa domowe dotknięte, obok ubóstwa dochodowego, również ubóstwem mieszkaniowym.

\section{LITERATURA}

1. Andrzejewski A., Polityka mieszkaniowa, PWE, Warszawa 1987.

2. Bywalec Cz., Rudnicki L., Podstawy ekonomiki konsumpcji, Wyd. Akademii Ekonomicznej w Krakowie, Kraków 1999.

3. Gierszewska R., Łopato J., Zamożność, dochody, ubóstwo, świadczenia społeczne [w:] Polityka spoteczna, red. G. Firlit-Fesnak, M. Szylko-Skoczny, Wydawnictwo Naukowe PWN, Warszawa 2009.

4. GUS, Sytuacja społeczno-ekonomiczna gospodarstw domowych w latach 2000-2015.

5. Hodoly A., Gospodarstwo domowe i jego rola społeczno-ekonomiczna, Wyd. KiW, Warszawa 1971.

6. Kramer J., Konsumpcja w gospodarce rynkowej, PWE, Warszawa 1997.

${ }^{21}$ A. Napiórkowska-Baryła, M. Witkowska-Dąbrowska, N. Świdyńska, Subsydiowanie wydatków mieszkaniowych jako instrument socjalnej polityki mieszkaniowej, Zeszyty Naukowe WSES w Ostrołęce 4/2016(23), s. 195-208. 
7. Krzeczkowski K., Kwestia mieszkaniowa $w$ miastach polskich, Związek Miast Polskich, Warszawa 1939.

8. Napiórkowska-Baryła A., Witkowska-Dąbrowska M., Świdyńska N., 2016, Subsydiowanie wydatków mieszkaniowych jako instrument socjalnej polityki mieszkaniowej. Zeszyty Naukowe WSES w Ostrołęce 4/2016(23).

9. Olechowski K., Załęcki P., Słownik socjologiczny, Graffiti BC, Toruń 1999.

10. Szelągowska A., Finansowanie społecznego budownictwa mieszkaniowego, Wyd. CeDeWu, Warszawa 2011.

11. Wiszniewski E., Ekonomika konsumpcji, PWN, Warszawa 1983.

12. Żelazna K., Kowalczuk I., Mikuta B., Ekonomika konsumpcji. Elementy teorii, Wyd. SGGW, Warszawa 2002.

\section{NETOGRAFIA}

1. Gorczyca M., Zaległości w optatach za użytkowanie mieszkań, 2017, http://www.administrator24.info/artykul/id9688,zaleglosci-w-oplatach-za-uzytkowanie-mieszkan (dostęp: 10.10.2017 r.).

2. Kędzior Z., Relacje konsument - gospodarstwo domowe jako przedmiot badań marketingowych [w:] Kontrowersje wokót marketingu w Polsce - tożsamość, etyka przyszłość red. L. Garbarski, Wyd. Wyższej Szkoły Przedsiębiorczości i Zarządzania im. L. Koźmińskiego, Warszawa 2004, https://books.google.pl/books?isbn=8389437333 (dostęp: 10.10.2017 r.).

\section{CONSUMER EXPENDITURE ON HOUSING VERSUS DUE RENT AND HOUSING BILLS IN HOUSEHOLD BUDGETS}

In the theory of economy, consumption is perceived as a process of satisfying people's needs. There are numerous divisions and classifications of needs, defined as 'a certain psycho-physical condition of a person, which reflects itself in a subjective feeling of a lack or desire to own some goods or to achieve a certain status', which have arisen from research in the fields of both psychology and economy. Unquestionably, one of the essential needs is to have a place to live. While the purchase of a flat or house does not belong to the realm of consumer spendings, the costs incurred by using and maintaining one's home are a fixed item in the budget of a household. The purpose of this article has been to identify trends which appear in the structure of consumption expenditure among households, and in particular the expenses associated with the maintenance of a house or a flat in the years 2000-2015. Additionally, the level of housekeeping expenditure has been compared to the amounts of due payments for rent and bills, making a distinction between different forms of property rights, and confronted with the indices measuring poverty in Poland and the EU. It has been determined which forms of property rights to a house or a flat coincide with the highest sums of due payments for the rent and other housing bills.

Keywords: housing needs, housekeeping expenses, due rent and other housing bills.

DOI: $10.7862 /$ rz.2018.hss.50

Przestano do redakcji: listopad 2017 r.

Przyjęto do druku: wrzesień 2018 r. 